07,01

\title{
Дефектная структура и термомеханическая стабильность нано- и микрокристаллического титана, полученного разными методами интенсивной пластической деформации
}

\author{
(C) В.И. Бетехтин ${ }^{1}$, V. Sklenicka ${ }^{2}$, А.Г. Кадомцев ${ }^{1}$, Ю.Р. Колобов ${ }^{3}$, М.В. Нарыкова ${ }^{1}$ \\ ${ }^{1}$ Физико-технический институт им. А.Ф. Иоффре РАН, \\ Санкт-Петербург, Россия \\ ${ }^{2}$ Institute of Physics of Materials, Academy of Sciences of the Czech Republic, \\ Brno, Czech Republic \\ ${ }^{3}$ Институт проблем химической фиизики РАН, \\ Черноголовка, Россия \\ E-mail: vladimir.betekhtin@mail.ioffe.ru
}

(Поступила в Редакцию 24 октября 2016 г.)

Исследованы механическая стабильность при длительном нагружении и термостабильность при отжиге нано- и микрокристаллического титана, полученного разными методами интенсивной пластической деформации. Выявлено и проанализировано влияние на термомеханическую стабильность нанопористости и доли большеугловых границ, сформировавшихся в результате интенсивной пластической деформации. Установлено, что в зависимости от температуры нагружения или отжига существенное влияние на термомеханическую стабильность титана помимо указанных выше структурных характеристик могут оказывать либо двойниковые границы зерен, либо дисперсные частицы карбида титана.

Исследование выполнено за счет гранта Российского научного фонда (проект № 15-12-30010).

DOI: 10.21883/FTT.2017.05.44383.391

\section{1. Введение}

Титан и сплавы на его основе находят широкое применение: от аэрокосмической техники до изделий биомедицинского назначения. В связи с этим разработка путей получения титана с высокими механическими характеристиками и исследование структурных особенностей, их определяющих, являются одной из важных задач современного материаловедения. В настоящее время для решения этой задачи широко используется перевод титана [1-4], как и других металлов и сплавов [5-7], в нанои микрокристаллическое состояние за счет воздействия различных режимов интенсивной пластической деформации (ИПД). Основными структурными факторами, определяющими высокие механические характеристики после ИПД, являются размер зерен, состояние и структура границ зерен, включая их разориентацию.

Следует, однако, учитывать, что из-за накопления при ИПД большой избыточной энергии границы нанои микрозерен находятся в неравновесном состоянии. В силу этого изучение влияния внешних механических и термических воздействий на неравновесную дефектную структуру и, как следствие, на высокопрочное состояние, которое эта структура обусловливает, становится актуальным для решения ряда фундаментальных и прикладных вопросов физики прочности [8].

В настоящей работе рассмотрены результаты исследования влияния дефектной структуры и внешних воздействий (температуры, нагрузок) на механическую и термическую стабильность нано- и микрокристалли- ческого титана, полученного разными методами ИПД. Для оценки механической стабильности, которая имеет важное значение особенно при длительных нагружениях, проводилось сопоставление влияния величины нагрузки на долговечность при испытании полученных разными методами ИПД образцов в условиях ползучести. Термостабильность оценивалась по влиянию на механические свойства (в основном микротвердость) температуры и времени отжига.

\section{2. Материал и экспериментальные методики}

В качестве материала для исследования использовались различные партии технически чистого титана BT1-0, суммарное содержание примесей в которых составляло $0.3 \mathrm{wt} . \%$.

Для ИПД с помощью винтовой и продольной прокатки (ВПП) использовались две партии (партии $A$ и $B$ ) титана ВТ1-0, содержание примесей $(\mathrm{H}, \mathrm{N}, \mathrm{Fe}, \mathrm{O}, \mathrm{Al}$, $\mathrm{Si}$ в в которых было практически одинаковым. Основное различие партий заключалось в том, что, как установлено методом энергодисперсионной рентгеновской спектроскопии, содержание углерода в партии $B$ было в 2 раза больше, чем в партии $A$. Режим ВПП для обеих партий был одинаков: поперечно-винтовая прокатка от диаметра 30 до диаметра $20 \mathrm{~mm}$ при $673 \mathrm{~K}$; продольная прокатка при $673 \mathrm{~K}$ до диаметра $12 \mathrm{~mm}$; поперечновинтовая прокатка при $293 \mathrm{~K}$ до диаметра $8 \mathrm{~mm}$. В за- 
ключение полученные после ВПП заготовки отжигались при $623 \mathrm{~K}$ в течение $3 \mathrm{~h}[9,10]$.

Для ИПД с помощью криопрокатки использовался титан ВТ1-0, близкий по составу примесей к партии $A$ с пониженным содержанием углерода. Прокатка проводилась при температуре, близкой к температуре жидкого азота до относительной деформации 86\% [11].

Структурные исследования проводились с помощью растрового электронного микроскопа (Quanta 600 FEG) с полевой эмиссией и просвечивающего электронного микроскопа (Philips CM12) с использованием обратного электронного рассеяния, позволяющего получить информацию о распределении зерен по разориентации.

Определение плотности (свободного объема) и ее изменения при ИПД проводилось прецизионным методом гидростатического взвешивания, относительная погрешность измерения не превышала $10^{-4}$. Модифицированным методом рентгеновского рассеяния в области сверхмалых углов определялись параметры неоднородностей электронной плотности: нанопор, возникающих при ИПД, и неметаллических дисперсных включений [9].

Механические испытания проводились либо при растяжении с постоянной скоростью деформации $2 \cdot 10^{-4} \mathrm{~s}^{-1}$ при комнатной температуре на установке Instron 5882, либо в условиях ползучести при постоянстве напряжения и температуры в процессе испытания каждого образца, либо при измерении микротвердости. С помощью указанных методов определялись предел прочности и текучести, долговечность (время до разрушения при длительных испытаниях в условиях ползучести), величина микротвердости.

\section{3. Экспериментальные данные и их обсуждение}

Известно, что перевод металлов и сплавов за счет ИПД в нано- и микрокристаллическое состояние ведет к существенному повышению их механических характеристик: пределов прочности $\sigma_{B}$ и текучести $\sigma_{S}$, микротвердости $H_{v}$ и (при испытании в режиме ползучести или усталости) долговечности $\tau$ [5-7]. Это хорошо видно из данных, полученных на исследуемых образцах после их перевода в субмикрокристаллическое состояние за счет крио- и ВПП-прокаток (табл. 1). Однако, как показал анализ данных настоящей работы и литературных данных, степень повышения $\sigma_{B}, \sigma_{S}, H_{v}$ может значительно отличаться от полученной для долговечности (известны случаи, когда $\tau$ после перевода образца в микрокристаллическое состояние даже уменьшается) [10,12-17].

В связи с этим важно выяснить общие закономерности влияния ИПД на механическую стабильность $(\tau)$ высокопрочного титана, а также найти связь между эволюцией долговечности и особенностями образовавшейся после ИПД дефектной структуры.

В настоящей работе рассмотрены экспериментальные данные о влиянии механической нагрузки и температуры
Таблица 1. Механические свойства титана в различных структурных состояниях

\begin{tabular}{l|c|c|c|c}
\hline \multicolumn{1}{c|}{ Образец } & $\begin{array}{c}\sigma_{S}, \\
\mathrm{MPa}\end{array}$ & $\begin{array}{c}\sigma_{B}, \\
\mathrm{MPa}\end{array}$ & $\begin{array}{c}H_{v}, \\
\mathrm{~kg} / \mathrm{mm}^{2}\end{array}$ & $\delta, \%$ \\
\hline $\begin{array}{l}\text { Партии } A, B \\
\text { (исходное состояние) }\end{array}$ & 376 & 490 & 190 & 29 \\
Партия $A$ (после ИПД) & 670 & 850 & 275 & 12.5 \\
Партия $B$ (после ИПД) & 722 & 905 & 278 & 10 \\
Исходное состояние & 300 & 420 & 185 & 26 \\
(до криопрокатки) & & & & \\
После криопрокатки & 860 & 945 & 290 & 6.5
\end{tabular}

Таблица 2. Значения напряжения $\sigma$, температуры $T$ испытания и долговечности $\tau$ для титана, полученного криопрокаткой

\begin{tabular}{c|c|c}
\hline$\sigma, \mathrm{MPa}$ & $T, \mathrm{~K}$ & $\tau, \mathrm{h}$ \\
\hline 200 & 648 & 116 \\
200 & 673 & 32 \\
200 & 723 & 1.2 \\
100 & 723 & 42 \\
100 & 673 & 482 \\
200 & 673 & 6 \\
270 & 673 & 0.4
\end{tabular}

на механотермическую стабильность нано- и микрокристаллического Ti, полученного разными методами ИПД, и прежде всего достаточно эффективным и малоизученным методом криопрокатки.

Приготовленные после криопрокатки плоские образцы имели длину рабочей части $15 \mathrm{~mm}$ и размер поперечного сечения $3 \times 1 \mathrm{~mm}$. Испытания в условиях ползучести проводились при разных напряжениях и температурах. Типичные кривые ползучести приведены на рис. 1, 2. В табл. 2 указаны значения $\sigma, T$ и долговечности $\tau$ для всех исследованных криопрокатанных образцов, а на рис. 3 представлена зависимость долговечности от напряжения для образцов, испытанных при одной температуре (673 K).

Анализ показал, что зависимость достаточно хорошо может быть представлена уравнением

$$
\tau=A \exp (-\alpha \sigma), \quad T=\mathrm{const},
$$

где величина $\lg A$ равна значению $\lg \tau$ при $\sigma=0$.

На основании установленных нами ранее данных по влиянию $\sigma$ и $T$ на долговечность при испытании в режиме ползучести микрокристаллического титана серии $A$ и $B$, полученных методом винтовой и продольной прокатки $[9,10]$, в настоящей работе была построена зависимость $\lg \tau$ от $\sigma$ для испытанных при $673 \mathrm{~K}$ образцов (рис. 3). Видно, что, как и для криопрокатанных образцов, эта зависимость хорошо подчиняется уравнению (1) 


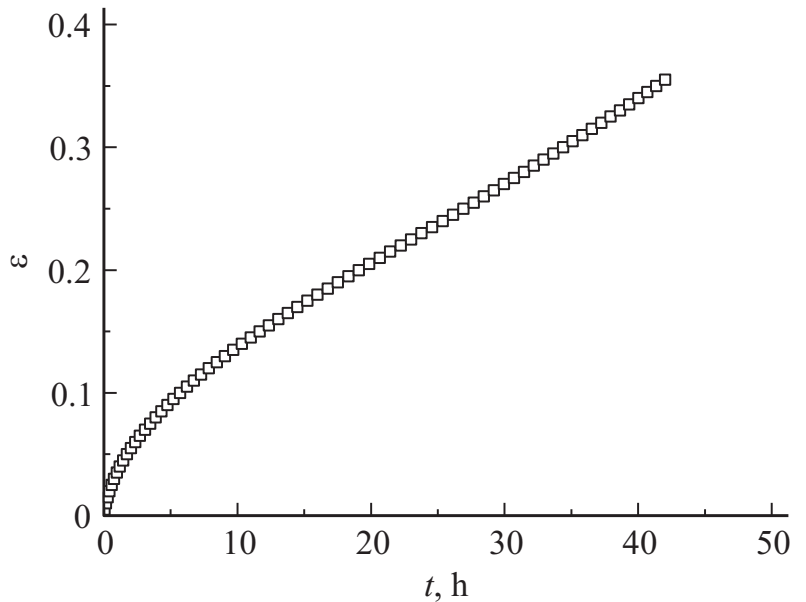

Рис. 1. Кривая ползучести для нанокристаллического титана, полученного методом криопрокатки. Испытания выполнены при $T=723 \mathrm{~K}, \sigma=150 \mathrm{MPa}$.

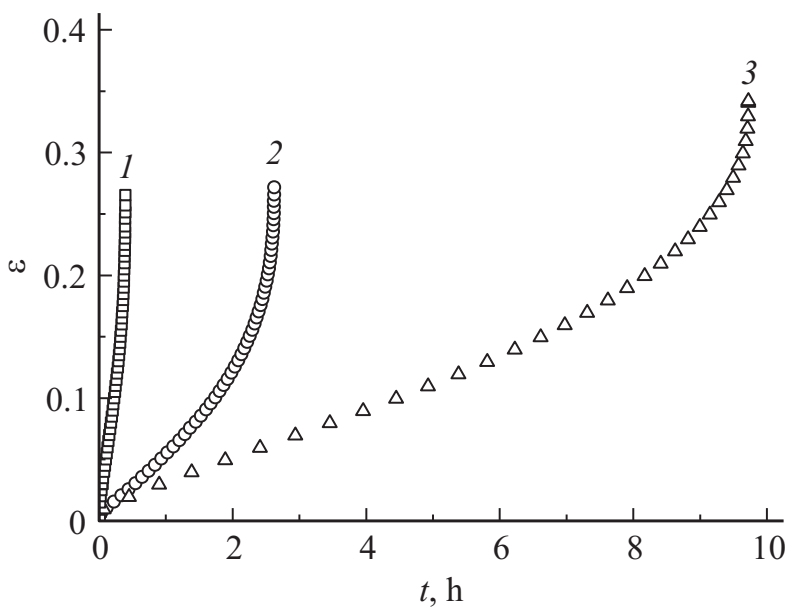

Рис. 2. Кривые ползучести титана. 1 - после криопрокатки, 2 - партия $A, 3$ - партия $B$. Испытания выполнены при $T=673 \mathrm{~K}, \sigma=270 \mathrm{MPa}$.

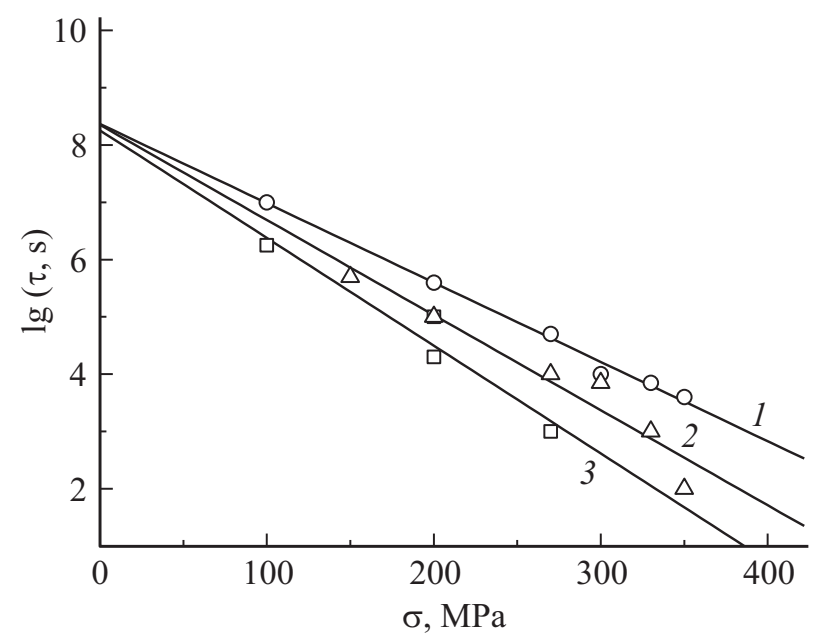

Рис. 3. Зависимость $\lg \tau$ от $\sigma$ для образцов титана. 1 партия $B, 2$ - партия $A, 3$ - после криопрокатки. Испытания выполнены при $T=673 \mathrm{~K}$. с практически одинаковым значением $A$; наблюдаются некоторые различия коэффициента $\alpha$ (наклона зависимости $\lg \tau$ от $\sigma$ ) для образцов после криопрокатки и ВПП-прокатки (партии $A$ и $B$ ).

Уравнение (1) является частным случаем общей зависимости [18]

$$
\tau=\tau_{0} \exp \left(\frac{U_{0}-\gamma \sigma}{k T}\right),
$$

в которой величина $U_{0}$ характеризует энергетический барьер, связанный с механизмом разрушения, а коэффициент $\gamma-$ структурно-зависимый коэффициент, являющийся показателем величины локальных напряжений, возникающих в нагруженном теле. Сопоставление уравнений (1) и (2) показывает, что $A=\tau_{0} \exp \frac{U_{0}}{k T}$, а $\gamma=\alpha k T$.

Таким образом, полученные в работе данные свидетельствуют о том, что (при постоянстве $\tau_{0}$ ) механизм процесса разрушения нано- и микрокристаллического титана $\left(U_{0} \sim A\right)$ одинаков, а сам процесс с учетом вида уравнений (1) и (2) и данных табл. 2 носит термоактивационный характер. При этом переход от криопрокатанного титана к ВПП-титану (партии $A$ и $B$ ) сопровождается последовательным увеличением уровня возникающих в процессе ползучести локальных напряжений $(\gamma \propto \alpha)$.

Сравнение кривых ползучести при идентичных $\sigma$ и $T$ для образцов Тi, полученных разными методами ИПД, показало, что наибольшей механической стабильностью (долговечностью) при $T \geq 573 \mathrm{~K}$ обладают образцы Ті партии $B$ с повышенным содержанием примеси углерода (и соответственно, как показано в [9], дисперсных частиц карбида титана), а наименьшей - образцы после криопрокатки. Последнее видно из рис. 2, на котором сопоставлены кривые ползучести, полученные при разных методах ИПД образцов нано- и микрокристаллического Ті при одинаковых условиях $(\sigma, T)$ нагружения.

Подобная ситуация для указанных образцов наблюдается и при сравнении их долговечности в широком интервале нагрузок при $673 \mathrm{~K}$ (рис. 3). Тем не менее хотелось бы отметить достаточно высокую механическую стабильность (долговечность) криопрокатанных образцов титана при длительных испытаниях. Так, оказалось, что долговечность криопрокатанных образцов Ті при $673 \mathrm{~K}$ и $\sigma=100 \mathrm{MPa} \mathrm{составляет} \mathrm{около} 20$ дней (табл. 2, рис. 3).

Рассмотрим полученные в работе данные о влиянии отжига на термическую стабильность нано- и микрокристаллического титана, полученного разными методами прокатки. На рис. 4, $a-c$ приведены данные о влиянии продолжительности отжига при различных температурах на микротвердость титана, полученного при криои винтовой (партии $A, B$ ) прокатках. Из приведенных данных видно, что после отжига при $T \geq 573 \mathrm{~K}$ максимальная термостабильность (как и механическая стабильность) наблюдается в микрокристаллическом Ті 
с повышенным содержанием дисперсных частиц карбида титана (партия $B$ ), а минимальная термостабильность в нанокристаллическом Ti, полученном криопрокаткой.

Тем не менее термостабильность нанокристаллического Ti, приготовленного криопрокаткой при различных температурах отжига, остается достаточно высокой по сравнению с термостабильностью других металлов,
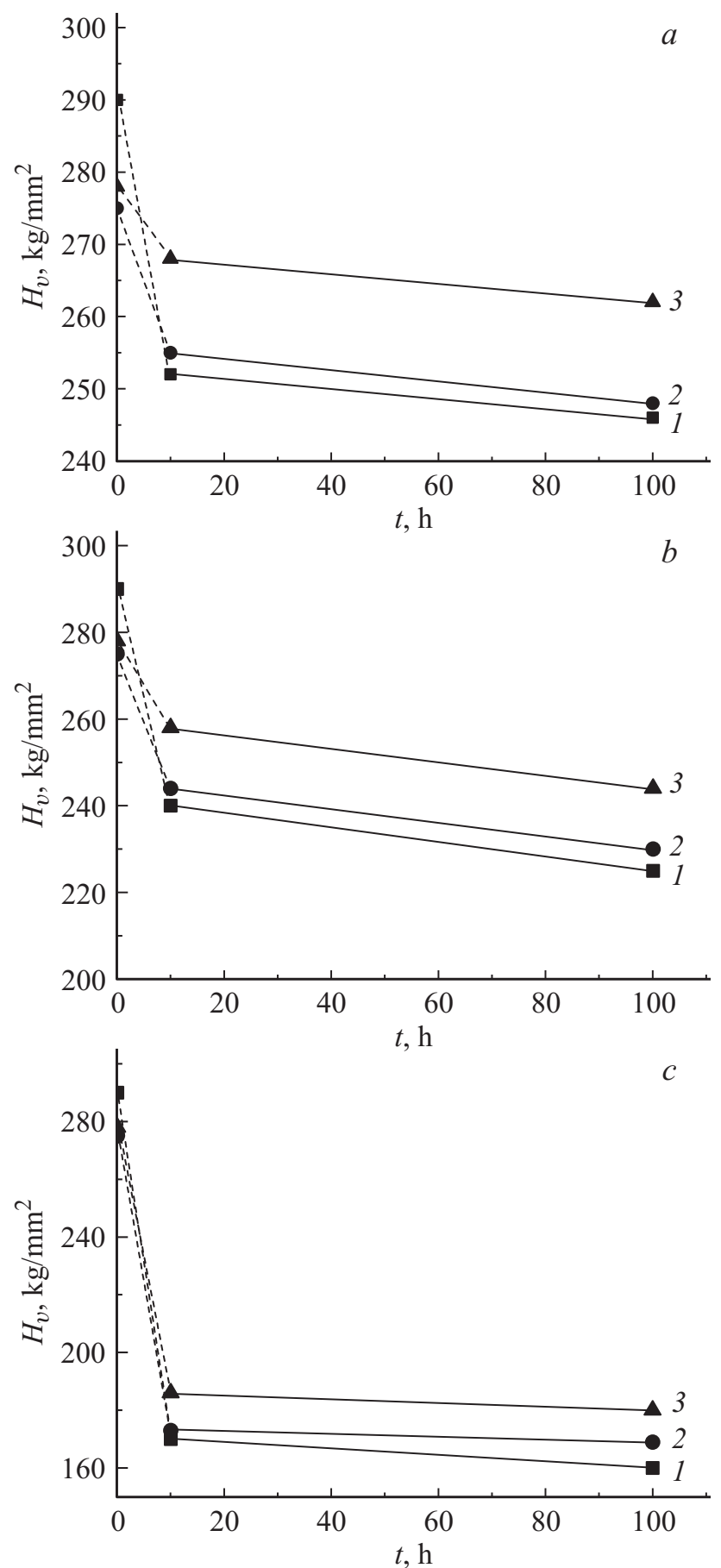

Рис. 4. Влияние продолжительности отжига при различных температурах на микротвердость $H_{v}$ титана. 1 - после криопрокатки, 2 - партия $A, 3$ - партия $B . T=573(a), 673(b)$, $773 \mathrm{~K}(c)$.

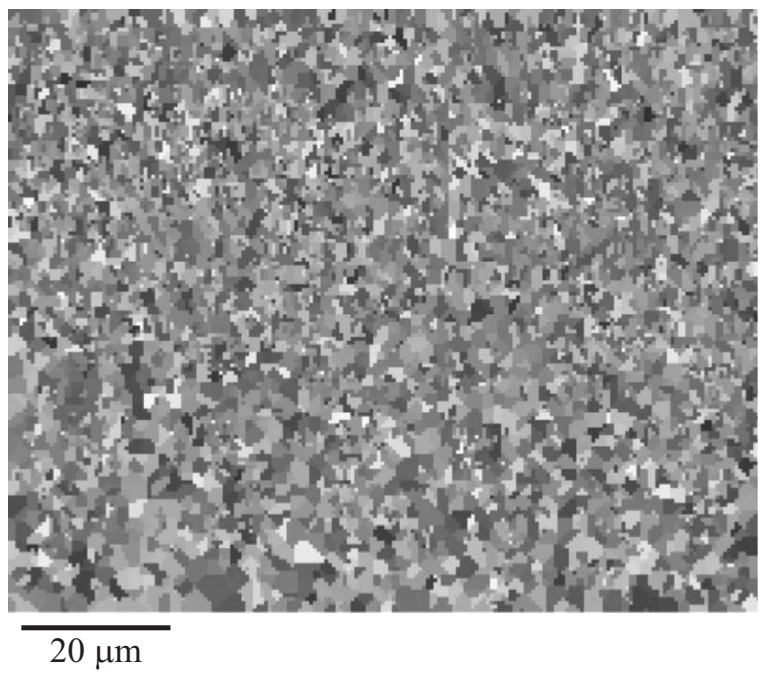

Рис. 5. Микроструктура титана, полученного методом криопрокатки, после отжига при $T=673 \mathrm{~K}$ в течение $10 \mathrm{~h}$.

подвергнутых криопрокатке, например меди [19], что связано с двойниковой природой границ зерен в криопрокатанном титане [11]. В связи с этим отметим, что, как установлено в данной работе, более высокая микротвердость криопрокатанного титана, чем в случае титана после ВПП (табл. 1), сохраняется до невысоких $(\leq 473 \mathrm{~K})$ температур отжига. Так, после отжига в течение $10 \mathrm{~h}$ при $473 \mathrm{~K}$ микротвердость криопрокатанного титана остается на $\sim 5.5 \%$ больше, чем у титана после ВПП, т.е. исходное различие микротвердости сохраняется (табл. 1, рис. 4). Это подтверждает важную роль в стабильности (по крайней мере при $T<473 \mathrm{~K}$ ) двойниковых границ. Резкое падение микротвердости $H_{v}$ (с 290 до $240 \mathrm{~kg} / \mathrm{mm}^{2}$ ) после отжига в течение $10 \mathrm{~h}$ при $673 \mathrm{~K}$ обусловлено, как было показано в настоящей работе, существенным (до $\sim 1 \mu \mathrm{m}$ ) укрупнением зерен (рис. 5).

Для анализа приведенных выше данных по механотермической стабильности нано- и микрокристаллического титана рассмотрим результаты его структурных исследований после крио- и ВПП-прокаток.

Установлено, что средний размер зерен после криопрокатки $\sim 35 \mathrm{~nm}$, при этом распределение зерен по размерам достаточно узкое, максимально наблюдаемый размер около $70 \mathrm{~nm}[11]$. После ВПП средний размер зерен в партиях $A$ и $B$ практически одинаков и составляет $190 \pm 0.06$ и $180 \pm 0.01 \mathrm{~nm}$ соответственно [9].

Распределения зерен по разориентации, полученные в данной работе для партий $A, B$ и для криопрокатанных образцов, качественно близки (рис. 6): имеется узкий пик в области малоугловых границ; максимально наблюдаемая разориентация около 90 , доля большеугловых границ зерен (HAGB) достаточно высокая. При этом величина HAGB в партиях $A$ и $B$ практически одинакова (64 и 68\% соответственно), а в криопрокатанном образце несколько меньше (56\%). 

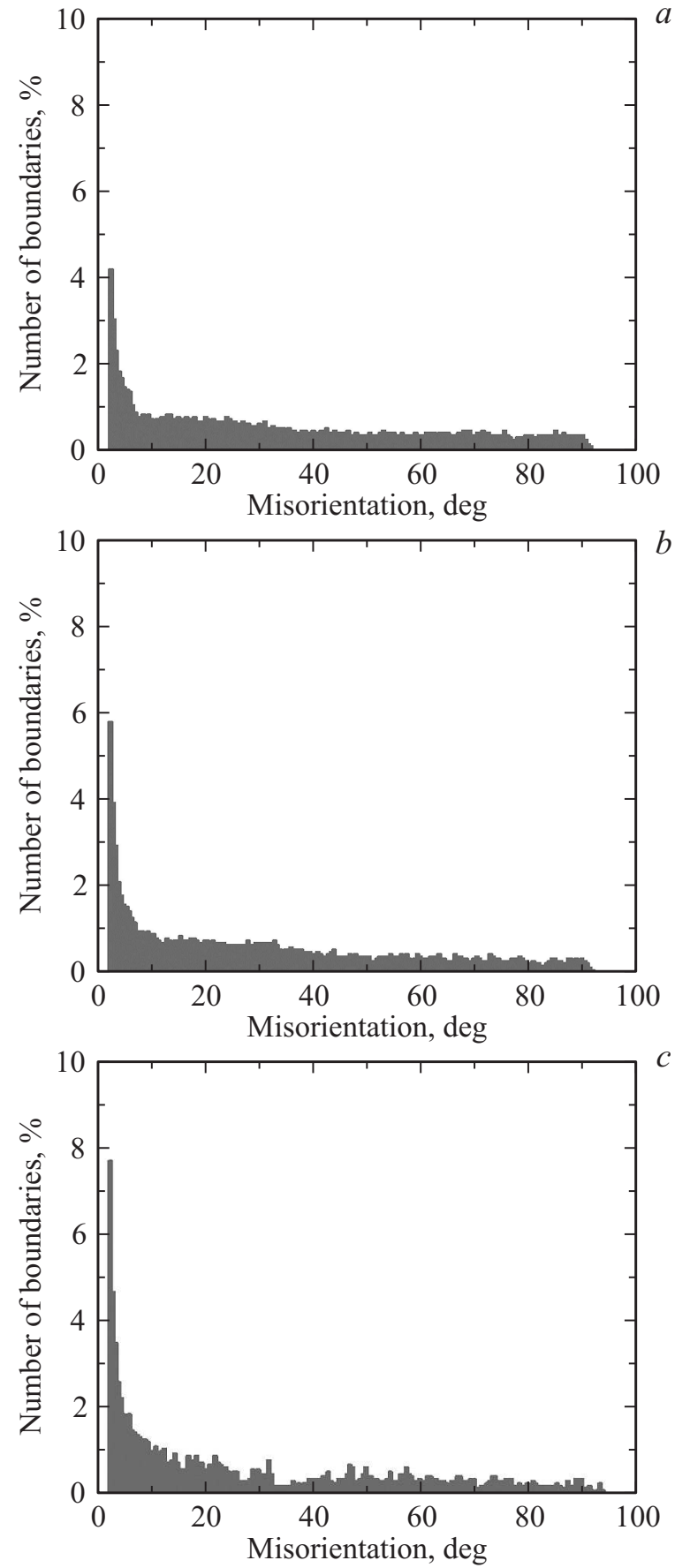

Рис. 6. Распределение зерен по разориентации для титана партии $A(a)$, партии $B(b)$ и после криопрокатки $(c)$.

Помимо размера зерен и величины HAGB существенное значение для формирования механических свойств металлов в процессе их ИПД имеет образование свободного объема, связанного в основном с неравновесными границами зерен и их тройных стыков. Важной количественной характеристикой свободного объема является величина изменения после ИПД плотности $\rho$ металла, которая отражает в основном степень „разрыхления“ границ за счет локализации в них дислокаций, вакансий и их комплексов - нанопор. Установлено, что максимальное относительное разуплотнение (величина $\Delta \rho / \rho$ ) после ИПД в исследованных после криопрокатки образцах составляет $\sim 1.3 \cdot 10^{-3}$; в партиях $A$ и $B-6 \cdot 10^{-4}$ и $9 \cdot 10^{-4}$ соответственно, т. е. заметно меньше. Данные малоуглового рентгеновского рассеяния, полученные в [9] и в настоящей работе, показали, что концентрация нанопор размером $\sim 10-30 \mathrm{~nm}$ максимальна (как и разуплотнение) в образцах после криопрокатки.

При этом концентрация нанопор (как и величина $\Delta \rho / \rho)$ в образцах партии $B$ больше, чем в образцах партии $A$. Представляется, что различие в степени нанопористости объясняется тем, что образцы партии $B$ содержат более высокую, чем в партии $A$, концентрацию включений карбида титана размером $\sim 5-10 \mathrm{~nm}$. Это дает основание полагать, что при одинаковом режиме ВПП именно повышенное содержание ТіС в образцах партии $B$ привело к более интенсивному образованию нанопористости при ИПД. Отметим, что интенсифицирующее влияние дисперсных частиц на образование нанопор при ИПД было обнаружено и в сплаве $\mathrm{Al}+0.2 \% \mathrm{Sc}$ (содержащем наночастицы $\mathrm{Al}_{3} \mathrm{Sc}$ ) при его равноканальном угловом прессовании [15].

Рассмотрим с учетом результатов структурных исследований и их предварительного анализа полученные данные о прочности и ее стабильности в нано- и микрокристаллическом титане.

Представляется, что более высокая прочность $\left(\sigma_{S}, \sigma_{B}, H_{v}\right)$ для наноструктурного криопрокатанного титана по сравнению с прочностью микрокристаллического титана, полученного после ВПП, обусловлена главным образом более мелким размером зерен после ИПД. Небольшое повышение прочностных характеристик титана партии $B$ по сравнению с таковыми в случае партии $A$ связано, вероятно, с повышенной концентрацией в партии $B$ наноразмерных частиц карбида титана (размер зерен и величины HAGB в партиях $A$ и $B$ практически одинаковы, а концентрация свободного объема и нанопористость в партии $B$ даже несколько больше, чем в партии $A)$.

При сравнении механической стабильности в процессе длительного нагружения при $T \geq 573 \mathrm{~K}$ более низкую долговечность криопрокатанного наноструктурного Ті, чем для полученного при ВПП микрокристаллического Ti, можно объяснить в основном его более высокой „исходной“ (образовавшейся после ИПД) нанопористостью.

Действительно, ранее было показано, что эта „исходная“" нанопористость существенно влияет на долговечность $\mathrm{Al}$ и сплава $\mathrm{Cu}+0.2 \% \mathrm{Zr}$ : залечивание под действием высокого гидростатического давления образовавшейся после ИПД нанопористости позволило повысить долговечность [20,21].

С учетом отмеченного выше более высокую долговечность титана партии $B$ (по сравнению с $\tau$ для партии $A$ ) можно объяснить упрочняющим влиянием на механическую стабильность повышенной концентрации частиц карбида титана. При длительном нагружении в 


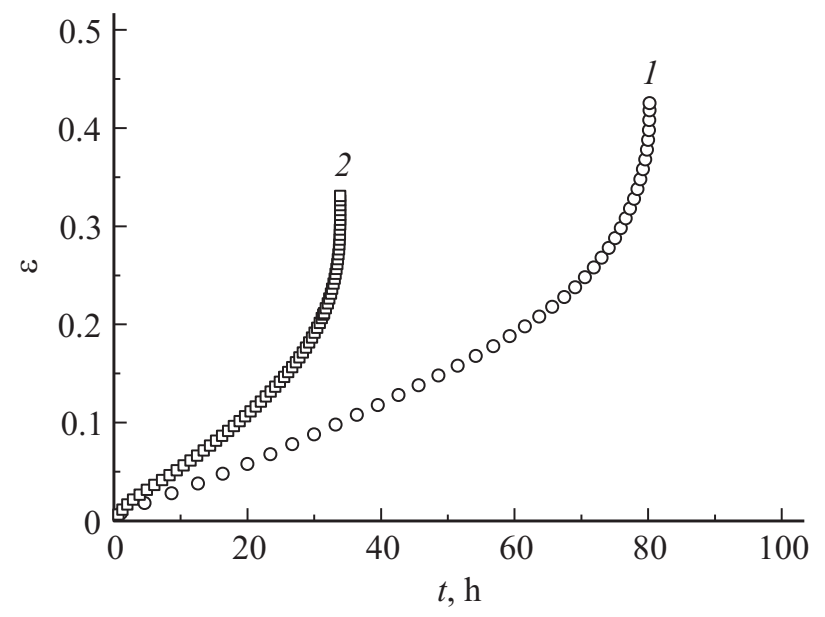

Рис. 7. Кривые ползучести микрокристаллического титана. 1 - после ВПП (партия $A$ ), 2 - после РКУП (восемь проходов). Испытания выполнены при $T=673 \mathrm{~K}$ и $\sigma=150 \mathrm{MPa}$.

условии высокотемпературной ползучести это влияние, очевидно, полностью нивелирует негативное влияние нанопористости.

Однако при длительных низкотемпературных испытаниях в усталостном режиме влияние нанопористости на механическую стабильность может оказаться решающим. Действительно, длительные $\left(10^{7}\right.$ циклов) усталостные испытания при комнатной температуре показали, что механическая стабильность титана партии $A$ (предел выносливости $252 \mathrm{MPa)}$ выше, чем в случае партии $B$ (предел выносливости $214 \mathrm{MPa}$ ) $[9,10]$.

О влиянии „исходной“ (образовавшейся после ИПД) нанопористости на механическую стабильность микрокристаллического титана, полученного при равноканальном угловом прессовании (РКУП) и испытанного затем в режиме ползучести, свидетельствуют также данные работ $[12,22]$. В связи с этим отметим, что при ВПП, при которой возникает напряженное состояние, близкое к всестороннему сжатию с большой сдвиговой деформацией, интенсивность развития нанопористости меньше, чем при РКУП $[9,10]$, и, следовательно, механическая стабильность после ИПД должна быть выше. На рис. 7 показаны кривые ползучести при одинаковых условиях испытания для микрокристаллического титана, полученного после восьми проходов при РКУП [12] и после ВПП (партия $A$, данные настоящей работы). Оценка разуплотнения показала, что после РКУП разуплотнение $(\Delta \rho / \rho) \approx 1 \cdot 10^{-3}$, а после ВПП $(\Delta \rho / \rho) \approx 6 \cdot 10^{-4}$. Эти данные подтверждают влияние пористости на долговечность. Отметим, что значения HAGB для образцов после РКУП (57\%) и ВПП (64\%) близки.

Помимо нанопористости существенный вклад в снижение механической стабильности нано- и микрокристаллических металлов и сплавов, полученных при ИПД, вносит образование большеугловых границ [20]. Большеугловые границы, особенно их тройные стыки, являются источниками высоких локальных внутренних напряжений, увеличивающихся с ростом НAGB. Представляется, что именно в условиях длительного нагружения высокие напряжения, локализованные в большеугловых границах, инициируют развитие повреждаемости и другие структурные изменения, которые и ведут к снижению долговечности. При этом на характеристики „кратковременной“ прочности $\left(\sigma_{S}, \sigma_{B}, H_{v}\right)$ образование HAGB оказывает положительное влияние.

В свою очередь негативное влияние на механическую стабильность „исходной“ пористости можно связать с тем, что либо нанопоры становятся „очагами“ развития повреждаемости при длительном нагружении, либо они, как и HAGB, интенсифицируют межзеренное скольжение и динамическую рекристаллизацию в процессе испытания в исследованном режиме ползучести.

Предварительный анализ вклада как нанопористости, так и HAGB в снижение механической стабильности свидетельствует о том, что залечивание „исходных“ нанопор эффективно повышает механическую стабильность только в тех образцах, в которых доля НAGB сравнительно невелика (например, после одного-двух проходов при РКУП). При существенном увеличении доли HAGB их негативное влияние в условиях длительного нагружения, очевидно, полностью нивелирует положительный для механической устойчивости эффект залечивания нанопор $[10,20,21]$.

\section{4. Заключение}

Анализ полученных данных свидетельствует о том, что на термомеханическую стабильность высокопрочного нано- и микрокристаллического титана влияют образовавшиеся в процессе интенсивной пластической деформации нанопоры и большеугловые границы зерен. Уровень сформировавшейся в процессе ИПД нанопористости и НAGB и определяют, очевидно, скорость термоактивационного процесса развития повреждаемости и других структурных изменений, обусловливающих термомеханическую стабильность нано и микрокристаллического титана при его длительном нагружении. Существенный вклад в термомеханическую стабильность вносят также двойниковые границы зерен и наноразмерные частицы включений типа карбида титана, роль которых во многом определяется внешними условиями, особенно температурой.

Авторы благодарят В.А. Москаленко (ФТИНТ, Харьков) за предоставление криопрокатанного титана.

\section{Список литературы}

[1] Е.Ф. Дударева, Г.П. Бакач, Г.П. Грабовенков, Ю.Р. Колобов, О.А. Кашин, Л.В. Чернова. Физическая мезомеханика 4, 1, 97 (2001).

[2] И.И. Кузменко, Ю.Р. Колобов, Е.А. Корнеева, Г.В. Хромов, А.А. Горяйна. Рос. нанотехнологии 8, 5-6, 20 (2013). 
[3] P. Kral, J. Dvorak, M. Kvapilova, V. Sklenicka, S. Zherebtsov, G. Salishev. J. Mater. Sci. 48, 13, 4789 (2013).

[4] C.-Y. Hyun, H.-K. Kim. Rev. Mater. Sci. 28, 1, 69 (2011).

[5] H. Gleiter. Nanostruct. Mater. 1, 1 (1992).

[6] Р.А. Андриевский, А.М. Глезер. УФН 179, 4, 337 (2009).

[7] В.З. Валиев, Г.В. Александров. Наноструктурные материалы, полученные интенсивной пластической деформацией. Логос, М. (2000). 272 с.

[8] Р.А. Андриевский. Успехи химии 83, 4, 365 (2014).

[9] В.И. Бетехтин, Ю.Р. Колобов, V. Sklenicka, А.Г. Кадомцев, М.В. Нарыкова, J. Dvorak, Е.В. Голосова, Б.К. Кардашев. ЖТФ 85, 1, 66 (2015).

[10] В.И. Бетехтин, А.Г. Кадомцев, М.В. Нарыкова. В кн.: Многофункциональные конструкционные материалы нового поколения. СибГИУ, Новокузнецк (2015). С. 296.

[11] В.А. Москаленко, В.И. Бетехтин, Б.К. Кардашев, А.Г. Кадомцев, А.Р. Смирнов, Р.В. Смолянец, М.В. Нарыкова. ФTT 56, 8, 1539 (2014).

[12] В.И. Бетехтин, J. Dvorak, А.Г. Кадомцев, Б.К. Кардашев, М.В. Нарыкова, Г.К. Рааб, V. Sklenicka, С.Н. Фаизова. Письма в ЖТФ 41, 2, 58 (2015).

[13] V. Sklenicka, J. Dvorak, P. Kral, M. Svoboda, M. Kvapilova, V.I. Kopylov, S.A. Nikulin, S.V. Dobatkin. Acta Phys. Pol. A 122, 3, 485 (2012).

[14] V. Sklenicka, J. Dvorak, T.G. Langdon. Mater. Sci. Eng. A 558, 403 (2012).

[15] В.И. Бетехтин, V. Sklenicka, I. Saxl, Б.К. Кардашев, А.Г. Кадомцев, М.В. Нарыкова. ФТТ 52, 8, 1517 (2010).

[16] В.Ф. Терентьев, С.В. Добаткин, С.А. Никулин, В.И. Копылов, С.О. Рогачев, И.О. Банных. Деформация и разрушение материалов 8, 26 (2010).

[17] P. Kral, M. Svoboda, J. Dvorak, M. Kvapilova, V. Sklenicka. Acta Phys. Pol. A 122, 3, 457 (2012).

[18] В.Р. Регель, А.И. Слуцкер, Э.Е. Томашевский. Кинетическая природа прочности твердых тел. Наука, М. (1979). $560 \mathrm{c}$.

[19] T. Konkova, S. Mironov, A. Korznikov, S.L. Scmiatin. Acta Mater. 58, 16, 5262 (2010).

[20] В.И. Бетехтин, А.Г. Кадомцев, V. Sklenicka, М.В. Нарыкова. Письма в ЖТФ 37, 20, 75 (2011).

[21] J. Dvorak, V. Sklenicka, V.I. Betekhtin, A.G. Kadomtsev, P. Kral, M. Kvapilova, M. Svoboda. Mater. Sci. Eng. A 584, 103 (2013).

[22] В.И. Бетехтин, А.Г. Кадомцев, М.В. Нарыкова, О.В. Амосова, V. Sklenicka. Письма в ЖТФ 43, 1, 38 (2017). 